\title{
National Economic Empowernment Development Strategy (NEEDS) as a Panacea for Employment Creation and Self Employment and Self Reliant
}

\author{
lyamu Ewemade Ph.D \\ Department of Vocational and Technical Education, Faculty of Education, \\ University of Benin, Benin City, Edo State, Nigeria \\ Email:drewemadeiyamu@gmail.com \\ Ojeaga Ibhade Joy (Mrs.) \\ Department of Vocational and Technical Education, Faculty of Education, \\ University of Benin, Benin City, Edo State, Nigeria \\ Email: joy4live2003@yahoo.com
}

\section{Doi:10.5901/jesr.2015.v5n2p61}

\section{Abstract}

This study assessed the ratings of lecturers in universities in Edo State on the role of entrepreneurship education in the realizations of NEEDS. Two research questions were formulated to guide the study. The population consisted of two hundred and sixty-four academic staff members from faculty of education and management of University of Benin and Ambrose Alli University. The survey research design was employed for the study. The instrument used was validated by three experts. Pearson's Product Moment Correlation coefficient was used to compute reliability of the instrument which yielded a correlation coefficient of 0.72. There was no sampling as the entire population was used for the study while two hundred and thirty six respondents were used for data analysis. Questionnaire was the instrument used for data collection. Data collected were analysed using the descriptive statistics. From the results of the analysis of data it was discovered that entrepreneurship education roles in meeting NEEDS goals in Edo State are creation of employment and self employment \& self reliant. Consequently, it was recommended among other things that a robust micro finance scheme be given top priority by government at all levels of governance. The development of entrepreneurship should be a major option for employment generation and income growth in Edo State. Edo State government should provide robust legislation towards encouragement and development of entrepreneurship education by commercial banks. Finally recommendations were made for further studies.

Keywords: Entrepreneurship Education, National Economic Empowerment Development Strategy (NEEDS), Employment, Self reliant, Self employment.

\section{Introduction}

The need for Entrepreneurship Education started emerging in the Mid-80's. Before now, unemployment and poverty were not pronounced as it is currently. However, political instability and inconsistencies in the social, economic policies of successive governments may have led to the emergence of high level of unemployment in our nation, Nigeria. In the face of the high level of unemployment, entrepreneurship education which could have salvaged the situation was not encouraged. The introduction of entrepreneurship education in higher education is intended to make the goal of higher education easily realizable as it seeks to make higher education entrepreneurship and business education graduates self-reliant and active participants of job creation and economic development.

Entrepreneurship Education is that aspect of Education which is intended to equip the students with the mindset, understanding, motivation and skills needed to achieve entrepreneurial success, (Ekpenyong 2010). Collins and Hannon (2006) considered Entrepreneurship Education as the pedagogy and business competences necessary for teaching business attitude, concepts, skills and knowledge. It is a programme that has its fundamental goals of monitoring of persons for definite function in entrepreneurial skills. It is intended to promote the learner in intellectual and occupational skills. These are skills that are intended to make them function effectively not only as employees but also self-reliant person and wealth creator. It seeks to prepare people particularly youth, to be responsible enterprising individuals who become entrepreneur or entrepreneurial thinkers by immersing them in real life learning experiences Oviawe and Anavberokhai (2008) asserted that in incorporating entrepreneurship characteristics and skills needed for starting small 
business enterprises, textbooks curriculum objectives and Technical Vocational Education (TVE) teachers programmes would ensure that entrepreneurship education in Nigeria addresses current realities and become adaptable for the aim of NEEDS, (National Economic Empowerment and Development Strategy) which is empowering people to become selfreliant and contribute to national development. Nwangwu (2007) opined that the failure of tertiary education to inculcate entrepreneurship education philosophy in students has led to wastages in terms of both human and natural resources.

The following can be said to represent the generally acceptable goals and objectives of entrepreneurship education.

i. To develop individuals who will be properly equipped with skills for productive work life.

ii. To develop individual who will be capable of meeting the modern business and technological challenges.

iii. To develop a pool of competent and reliable technical manpower, capable of being mobilized in times of national economic emergency.

iv. To develop in the youth the right attitudes and skills toward work; Equipping the youth with the requisite knowledge and skill for employee or self-employment;

v. To prepare the youth for meeting community skills and national economic aspirations

vi. To enable the youth to choose a perfect areas of business education for which they have interests and aptitudes;

vii. To equip the learners to develop skills for making rational economic decisions,

viii. To enable the learners to relate their expertise to the needs of their communities;

ix. To prepare business and industrial managers who will be capable of industry;

$\mathrm{x}$. To provide the vocational and technical knowledge in various areas of business;

The National Economic Empowerment Development Strategy (NEEDS) goals are directed towards the achieving the creation of employment and reduction of poverty, create smooth transition from tradition to a modern industrial economy that will serve as catalyst for economic development and growth and be able to inculcate the spirit of perseverance in the youths and adults which will enable them to persist in any business venture they embark on. Entrepreneurial education offers functional education for the people that will enable them to be self employed and self reliant, enabling youth, men and women to have an intelligent understanding of the increasing complexity of technology, identify self-employment opportunity in various business section and advise trainees or perspective entrepreneurs on selection of suitable venture to go into promoting the young graduates with enough training and support that will enable them to establish a career in a small and medium scale business.

Entrepreneurship education in tertiary institution is to inculcate NEEDS (National Economic and Development Strategy) philosophy in students that will not lead to waste in terms of both human and material resources. The lecturers as used in this study are those teachers employed to teach entrepreneurship education in the various tertiary institutions. These lecturers are either experienced or inexperienced, old and young teaching in either federal or state owned institutions. Experienced lecturers are those lecturers that have taught for more than ten years in their various institutions, while inexperienced lecturers are those who have taught less than ten years. The old lecturers are those lecturers who are 44 years and above, while young lecturers are those less than 25 years of age. Tertiary institutions are the federal and state universities in Edo State.

The concept of (NEEDS) National Economic Empowerment and Development Strategy as a programme emphasizes creation of employment opportunities, emphasis on self employment and self reliant for economic growth and development. All these are the main thrust of entrepreneurship education. It focuses on empowering citizens and if properly harnessed will address the societal needs into the much talked about economic, social-political, industrial and technological development. It is also believed that a well harnessed NEEDS can bring about the needed socio-economic development of a nation if properly managed.

Socio-economic development is a process that seeks to identify both the social and the economic needs within a community, and seek to create strategies that will address those needs in ways that are practical and in the best interests of the community over the long run. The general idea is to find ways to improve the standard of living within the area while also making sure the local economy is healthy and capable of sustaining the population present in the area (Wise GEEK, 2014).

The goals/objectives of the National Economic Empowerment and Development Strategy (NEEDS) are the nation plan for prosperity, coordinating action at both the federal and state levels. The NEEDS programme is based on the notion that these strategies can be achieved only by creating an enabling environment in which these goals can thrive.

Consequently, the Nigeria government is redirected to providing basic services for her citizens who are empowered to take advantage of the new livelihood opportunities (National Planning Commission, 2000). It sets out far 
reaching public reforms that state clearly that corruption and graft will be punished. It gives special support to agriculture industry, small and medium scale business. One sure route the NEEDS objective can be actualize is through education, most specifically entrepreneurship education and also provides the platform to readily achieve the goals of NEEDS.

The poor economic climate in our nation has worsened. The unemployment rate has necessitated the need to consider seriously the introduction of entrepreneurship education in the national educational system. Nwaokolo (1997), opined that education, training and experience can enhanced the supplying of entrepreneurs by making available more skills which are suitable for entrepreneurial educations. Osuala (1999), asserted that effective skill acquisition and entrepreneurship education as indispensable towards empowering people and producing a self-reliant nation with dynamic economy. He further reported that the strength of an economy depends on important aspects of the strength of its small business. The economic importance of entrepreneurship rests on job creation. Osuala asserted that a very rationale for promoting smalls scale business is their job creating potentials.

The major concern of this research work is to examine the role of entrepreneurship education in realizing federal government plan for empowering people through NEEDS. Entrepreneurship education is a panacea for national economic empowerment and development process. The primary aim of entrepreneurship education is to provide students with relevant and adequate skills to make a living. Tertiary institutions in Edo State have fully embraced entrepreneurship education programme.

The government at various times has emphasized the need for its citizen to look inwards for self employment due to the dwindling economic situations and the resultant massive unemployment of both youths and adult. It is worrisome to see youths and adults roaming the street probably they could not get government jobs or self employed. Graduate unemployment is a national threat capable of causing high degree of calamity in the society hence the introduction of National Economic Empowerment and Development Strategy (NEEDS) by the federal government of Nigeria. In spite of the laudable programme of NEEDS, there seems to large number of youths and adults roaming the street for jobs. What is not yet clear is to determine if the roles expected to play by NEEDS are played to reduce unemployment to barest minimum.

The major purpose of this study was to determine the role of entrepreneurship education in universities in Edo State in meeting National Economic Empowerment and Development Strategy. Specifically, this work will determine the following;

1. Importance of entrepreneurship education in creation of employment.

2. Relevance of entrepreneurship education to self employment and self reliant.

The study was based on two research questions as follows.

1. How important is entrepreneurship education in creation of employment?

2. How relevant is entrepreneurship education to self employment and self reliant?

\section{Method}

This study was a descriptive survey. The population of the study covered all the academic staff members in Faculty of education and faculty of Management Science in both University of Benin and Ambrose Alli University in Edo State. There are two (2) universities, made up of four (4) faculties, comprised of two hundred and sixty-four (264) staff. There was no sampling as the entire population was used for the study. A Questionnaire titled NEEDS for Employment Creation and Self Reliant (QNECSR) was used. The questionnaire has two sections which are Section "A" and "B" respectively. Section $A$ of the questionnaire is about the personal information of the respondents while Section $B$ of the questionnaire is to elicit data for the research work with research question 1consisting 17 items while research question 2 having 10 items. The 4-Point rating scale responses will be used to elicit information from the respondents. The responses are; Very Important (VI); Important (I); Fairly Important (FI); Not Important (NI) are Weighted 4, 3, 2, 1 respectively. The instrument was validated by three experts in the field of educational measurement and evaluation in University of Benin. Their corrections were effected in the final version of the instrument. The test retest method was adopted for the pilot study. The questionnaire was administered to the respondents who were not part of the population with an interval of two weeks. The data collected were treated with Pearson ' $r$ ' formula and a co-efficient of 0.78 was obtained and considered useful for the study. The prepared questionnaire was distributed through direct contact on the respondents with the help of two research assistants. 236 were retrieved and used for the study. The data collected were analyzed using mean, standard deviation and a z-test. Mean and standard deviation were used to answer all the research questions. Since the items were based on a 4- point scale with an average of 2.50, in interpreting the results, items with mean rating up to 2.50 and above were regarded as important while items below 2.50 were regarded as not important. 


\section{Result}

The data collected through the administration of the copies of the questionnaire to respondents were analysed using mean and standard deviation. The obtained mean and standard deviation were used to answer research questions 1 and 2 as presented in Tables 1 and 2 .

\subsection{Research Question 1}

From the rating of lecturers of public universities in Edo State, how important is entrepreneurship education in creation of employment?

To answer Research Question 1 the data were computed and the results are presented in Table 1.

Table 1: Rating of Lecturers in Respect of Employment Creation.

\begin{tabular}{|c|l|c|c|c|}
\hline S/n & Aspects of Employment Creation & Mean & S.D & Remark \\
\hline 1 & Ability to create employment opportunities & 2.90 & 1.13 & Important \\
\hline 2 & Ability to create jobs for NYSC members & 2.87 & 2.02 & Important \\
\hline 3 & Ability to work under pressure & 2.44 & 1.21 & N/important \\
\hline 4 & Ability to accept responsibility for one's action & 2.61 & 1.16 & Important \\
\hline 5 & Ability to take independent action & 2.93 & 1.18 & Important \\
\hline 6 & Ability to take calculated risk & 2.91 & 1.01 & Important \\
\hline 7 & Ability to take appropriate decision & 3.12 & 0.97 & Important \\
\hline 8 & Ability to demonstrate self-confidence & 3.24 & 0.84 & Important \\
\hline 9 & Ability to be goal oriented & 3.09 & 0.84 & Important \\
\hline 10 & Ability to be innovative & 2.89 & 1.05 & Important \\
\hline 11 & Ability to demonstrate the drive to achieve & 3.10 & 0.92 & Important \\
\hline 12 & Ability to motivate others to achieve & 3.11 & 0.99 & Important \\
\hline 13 & Ability to be imaginative and creative & 3.48 & 0.81 & Important \\
\hline 14 & Abilit0y to demonstrate resourcefulness in business & 2.95 & 0.99 & Important \\
\hline 15 & Ability to relate appropriately with people & 2.97 & 1.05 & Important \\
\hline 16 & Ability to work hard & 2.91 & 1.08 & Important \\
\hline 17 & Ability to be future oriented & 3.17 & 0.88 & Important \\
\hline & Grand Mean/Standard Deviation & 2.98 & 1.14 & Important \\
\hline
\end{tabular}

The data shown on table 1 revealed that mean ratings of the respondents ranged from 2.44 to 3.48 . The table shows that all the variables $(1-17)$ except variable three $(x=2.44)$ were rated as important. education.

The result shows that almost all the aspect of employment creation is made possible by entrepreneurship

\subsection{Research Question 2}

In the opinion of lectures of public universities in Edo State, how important is entrepreneurship education to self employment and self reliant?

The data collected in respect of this question are shown in table two thus indicating the mean ratings of lecturers on the importance of entrepreneurship education to self employment and self reliant. 
Table 2: Rating of Lecturers in Respect of Self Employment and Self Reliant.

\begin{tabular}{|c|l|c|c|c|}
\hline S/n & Aspects of Self Employment and Self Reliant & Mean & S.D & Remark \\
\hline 18 & Ability to identify and use market opportunities & 3.30 & 0.91 & Important \\
\hline 19 & Ability to evaluate business activities & 2.49 & 1.18 & F/Important \\
\hline 20 & Ability to plan effectively for goal attainment & 2.70 & 1.18 & Important \\
\hline 21 & Ability to determine the extent to which products will sell & 2.31 & 1.32 & F/Important \\
\hline 22 & Ability to set appropriate business goals & 2.94 & 0.97 & Important \\
\hline 23 & Ability to find out sources of capital to start business & 2.94 & 1.05 & Important \\
\hline 24 & Ability to use loan wisely & 3.26 & 0.94 & Important \\
\hline 25 & Ability to check day-to-day transactions & 2.99 & 1.04 & Important \\
\hline 26 & Ability to know registration procedures for small businesses & 2.15 & 1.08 & F/Important \\
\hline 27 & Ability to help create wealth & 2.65 & 0.94 & Important \\
\hline & Grand Mean/Standard Deviation & $\mathbf{2 . 7 8}$ & 1.06 & Important \\
\hline
\end{tabular}

The data shown on table 4 above revealed that mean ratings of the respondents ranged from 2.15 to 3.30 . The table shows that all the variables (18-27) except variables nineteen, twenty-one and twenty-six $(x=2.49,2.31 \& 2.15)$ were rated as important. self reliant.

The result shows that almost all the aspects of entrepreneurship education are important to self employment and

\section{Discussion of Findings}

In view of the results obtained from the presentation and analysis of data, the discussions of the major findings of the study are as follows:

The result of the analysis of research question 1 reveals that lecturers in Tertiary Institutions in Edo State rate entrepreneurship education as important in the creation of employment. Data on Table one which indicated the results contained seventeen items with total mean of 2.98. The theory of Schumpeter (1961) of innovations and dynamism is in consonance with the findings of this study.

The result of the analysis of research question 2 as shown in table 2 reveals that respondents in Tertiary Institutions in Edo State rates entrepreneurship education as relevant to self employment and self reliant. Isenmila (2009) has established that entrepreneurship is the language of business. Favell (1980) also states that entrepreneurship knowledge is an indispensable instrument to effective self employment and self reliant. These are in consonance with the results of the findings of the study.

\section{Conclusions}

Based on the findings of the study, I conclude that entrepreneurship education roles in meeting NEEDS goals in Edo State are creation of employment and self employment \& self reliant as rated by lecturers in Public universities in Edo State. Therefore, entrepreneurship education is needed for a paradigm shift to a developed society.

\section{Recommendations}

Deriving from the findings of this study, the following recommendations were made:

1. The development of entrepreneurship should be a major option for employment generation and income growth in Edo State.

2. Edo State government should provide robust legislation towards encouragement and development of entrepreneurship education by commercial banks.

3. A robust micro-credit scheme should be given top priority by the government both at local and state levels to enable graduates and all intending entrepreneurs to access funds as this will raise employment and enhance living standards. 


\section{References}

Agbaionu, E (2001). Adjusting NCE business education programme towards promotion of Entrepreneurial Success. Business Education Journal. 111 (4): 119-126.

Ajakaiye, J. (1999). Entrepreneurship Education and Training in Nigeria: Problems and prospects" paper presented in the National Conference on Entrepreneurship Education in Nigeria Tertiary institutions, Abuja, Nigeria, March 30 - April 1, 1999.

Akpomi, M. E. (2009). Achieving Millennium Development Goals (MDGS) through teaching Entrepreneurship Education in Nigeria Higher Education Institution (HEIs). European Journal of Social Sciences. 8(1), 152-159.

Ekpenyong, L.E. (2007). Towards a competence based business studies for secondary school leavers in Nigeria, Ibadan: Heinemann, Ed. Book, 45-50.

Ekpenyong, L.E. (2010). Vocational Technical Education and Entrepreneurship education: A practical approach. Ibadan: Heinemann, Ed. Books. 30-40.

Favell, P. F. (1980). Innovation and entrepreneurship: Practice and principles, (Paperback, Favell Series, Harper and Row, NY).

Isenmila, O.A. (2009). Entrepreneurship Development, First edition, Kota Success Publications, llorin.

National Planning Commission, (2000). National Economic Empowerment and Development Strategy (NEEDS) Abuja.

Nwangwu, I.G.O. (2007). Higher education for self-reliance: An imperative for the Nigerian economy. NEAP publication, 1-8.

Nwangwu, I. O. (2007). Entrepreneurship in education. Concept and constraints. African Journal of Education and Developmental Studies. 4(1), 196 - 207.

Nwaokolo, P.O. (1997). Entrepreneurship in technology education, In: N.P.M., Esomonu (eds) Entrepreneurship practices in education. Umunze: Research and Publication Unit, Federal College of Education (Technical), 11-25.

Osuala, E.C. (1995). Principles and practice of Small Business Management in Nigeria. A didactic approach: Nsukka: Falladu.

Osuala, E.C. (1999). Entrepreneurship in Small business forms. Lagos: G-Mag Educational Publishers.

Oviawe,J.J. \& Anavberokhai, M.O. (2008). Role of Entrepreneurship Education Empowerment and Development Strategy (NEEDS). G. Mag Educational publishers, Lagos 57-64.

Schumpeter, J. A. (1912/1934). English translation published in 1934. The theory of Economic Development. Cambridge, MA: Harvard University Press.

Smith, A.J. Collins, L.A. \& Hannon, P.D. (2006). Innovation in Entrepreneurship Educational Theory and Practice. 50-60

WiseGEEK (2014). What is socio-economic development? Retrieved on $15^{\text {th }}$ May 2014 from www.wisegeek.com/what-is-socioeconomic-development.htm

\section{Appendix}

\section{Questionnaire on Needs for Employment Creation and Self Reliant (QNECSR)}

\section{Section A}

Please tick $(\checkmark)$ the appropriate response that pertains to you.

\section{Section A: Personal Data}

1. Name of institution:-

2. Ownership of Institution:

3. Federal

4. Gender: Male

State

Female

\section{SECTION B}

Please, read the statements carefully and tick in the appropriate column to decide your option.

Rating Scale

$\begin{array}{lll}4= & \text { Very Important (VI) } \\ 3= & \text { Important (I) } \\ 2= & \text { Fairly Important (FI) } \\ 1= & \text { Not Important (NI) }\end{array}$




\begin{tabular}{|c|c|c|c|c|c|}
\hline $\mathrm{S} / \mathrm{N}$ & CREATION OF EMPLOYMENT & VI & $\mathrm{I}$ & $\mathrm{FI}$ & NI \\
\hline 1 & Ability to create employment opportunities & & & & \\
\hline 2 & Ability to create jobs for NYSC members & & & & \\
\hline 3 & Ability to work under pressure & & & & \\
\hline 4 & Ability to accept responsibility for one's action & & & & \\
\hline 5 & Ability to take independent action & & & & \\
\hline 6 & Ability to take calculated risk & & & & \\
\hline 7 & Ability to take appropriate decision & & & & \\
\hline 8 & Ability to demonstrate self-confidence & & & & \\
\hline 9 & Ability to be goal oriented & & & & \\
\hline 10 & Ability to be innovative & & & & \\
\hline 11 & Ability to demonstrate the drive to achieve & & & & \\
\hline 12 & Ability to motivate others to achieve & & & & \\
\hline 13 & Ability to be imaginative and creative & & & & \\
\hline 14 & Ability to demonstrate resourcefulness in business & & & & \\
\hline 15 & Ability to relate appropriately with people & & & & \\
\hline 16 & Ability to work hard & & & & \\
\hline 17 & Ability to be future oriented & & & & \\
\hline $\mathrm{S} / \mathrm{N}$ & SELF EMPLOYMENT AND SELF RELIANT & VI & $\mathrm{I}$ & $\mathrm{FI}$ & $\mathrm{NI}$ \\
\hline 18 & Ability to identify and use market opportunities & & & & \\
\hline 19 & Ability to evaluate business activities & & & & \\
\hline 20 & Ability to plan effectively for goal attainment & & & & \\
\hline 21 & Ability to determine the extent to which products will sell & & & & \\
\hline 22 & Ability to set appropriate business goals & & & & \\
\hline 23 & Ability to find out sources of capital to start business & & & & \\
\hline 24 & Ability to use loan wisely & & & & \\
\hline 25 & Ability to check day-to-day transactions & & & & \\
\hline 26 & Ability to know registration procedures for small businesses & & & & \\
\hline 27 & Ability to help create wealth & & & & \\
\hline
\end{tabular}


